\title{
Effect of levels of phosphorus and iron on growth, yield and quality of flax
}

\author{
Akram Othman Esmail ${ }^{1}$, Haifa Sediq Yasin ${ }^{2}$, Bahar Jalal Mahmood ${ }^{3}$ \\ ${ }^{I}$ (Soil and Water, Agriculture/ Salahaddin, Iraqi Kurdistan) \\ ${ }^{2}$ (Soil and Water, Agriculture/ Salahaddin, Iraqi Kurdistan) \\ ${ }^{3}$ (Field Crops, Agriculture/ Salahaddin, Iraqi Kurdistan)
}

\begin{abstract}
This study was conducted during the growing season of 2012-2013 from 1st December, 2012 to 26th of May, 2013 to study the effect of three levels of phosphorus $(0,50$ and $100 \mathrm{~kg} \mathrm{TSP} \mathrm{ha-1}$ and the three levels of Cheated iron $\left(0,4\right.$ and $\left.8 \mathrm{~kg} \mathrm{Fe}-E D D H A ~ h a^{-1}\right)$ and their combinations on growth characters, yield and quality of flax using split plot design with three replicates. The results indicated that the highest values of oil\%, oil yield, $P \%$, protein $\%$ and Fe concentration $\left(23 \%, 346.47 \mathrm{~kg} . \mathrm{ha}^{-1}, 6.65 \%, 27.47 \%\right.$ and $\left.151.90 \mathrm{ppm}\right)$ were recorded from treatment combinations $\left(P_{0} F e_{1}, P_{1} F e_{0}, P_{2} F e_{1}, P_{1} F e_{0}\right.$ and $\left.P_{2} F e_{2}\right)$ respectively. On the other hand increase in levels of applied phosphorus and iron caused increase in seed index from (5.65 to $6.53 \mathrm{~g}$ ) and from (5.24 to $6.39 \mathrm{~g}$ ) respectively.
\end{abstract}

Keywords: Flax, Oil content, Chelated-Fe, Calcareous soil

\section{Introduction}

Flax (Linum usitatissumum $L$ ) for seed production has emerged as an alternative crop species that allow increased diversification of cropping system in temperate environments (Khalifa et al., 2011).

Flax is grown all over the world for the oil extraction from the seeds and for its fibers, which are made into linen and other clothes. Various parts of the plant have been used to make fabric, dye, paper, medicines, fishing nets, hair gels and soap, it is also grown as an ornamental plants.

The seeds are widely used medically, which contains large amount of polyunsaturated fatty acids, alpha linoleic acid, which is an omega-3 fatty acid, linolenic acid which is an omega -6 fatty acid (Berti et al., 2009). Whole of crashed seeds are a reliable means of reliving constipation. The oil is also important in the manufacture of paints, soap and printers ink. (El-Nagdy et al., 2010).

It has a high percentage of essential fatty acid which plays a role in cell membrane synthesis by making them flexible, and affects several biological processes such as blood clotting and blood vessel contraction (ElHariri et al., 1998).

The cultivated area of flax is decreasing yearly, due to great competition of other economic winter crops resulting a gap between production and consumption. Therefore it is necessary to increase flax productivity per unit area which could be achieved by using high yielding cultivars and improving the fertilization (Hussein, 2007) and improving the agricultural treatments (Nofal et al., 2011 and Grant et al., 2012).

One of these treatments is mineral fertilizers which are regarding as important factors for vigorous growth and consequently higher yield of different plant species (McKenzie and Allan, 2013).Nutritional disorders creating deficiency symptoms can be affected by un balanced fertilizer application, on the other hand the availability of $\mathrm{P}$ and micronutrients such as $\mathrm{Fe}, \mathrm{Mn}, \mathrm{Zn}$ and $\mathrm{Cu}$ are affecting by soil $\mathrm{pH}$, soil $\mathrm{CaCO} 3$ content, soil organic matter and soil texture (Mengel and Frnest, 2010).

Phosphorus fertilization has great effect on crop production especially in calcareous soils. To optimize crop nutrition, P must be available to the crop in adequate amounts during the growing season (You et al., 2007).

Plants need P throughout their life cycle, especially during early growth stages for cell division and during maturity stage for seed formation and increase in seed weight. Placement of $\mathrm{P}$ in-row with cereal and oilseed crops has been the traditional method used for P fertilization in Alberta (Lafoand et al., 2003).

$\mathrm{P}$ is mobile in the plant, so it is absorbed during early growth and is later redirected for use in seed formation (Roy et al., 2007).

Higher P levels increased the yield and $\mathrm{N}$ use efficiency (Bakry et al., 2012).The medium to high soil P levels to optimize flax yields was recommended (Mousavi, 2011).

Iron is an essential micro element for plant growth; it plays an important role in the formation of chlorophyll A and chlorophyll B, carbohydrate production, cell respiration and chemical reduction of nitrate (Mousa et al., 2010). Iron is also necessary for the proper functioning of many plant enzyme systems that influence respiration and plant metabolism and helps oxidize sugar for energy (Ibrahim, 2009). 
Micronutrients especially $\mathrm{Fe}$ and $\mathrm{Zn}$ are playing an important role in activity of enzymes or as functional, structural or regulatory cofactors (Cynthia et al., 2004).

Since the availability of phosphorus and iron is low in calcareous soil, due to high soil $\mathrm{pH}$ and high $\mathrm{CaCO}_{3}$ content of the soil, this reduces the ability of nutrient uptake by plants (Hocking and Jand, 1993). For these reasons this study was selected to high light on the effect of levels of phosphorus and iron on growth characters, yield and quality of flax.

\section{Material and methods}

The field experiment was laid out at Grdarasha Agricultural farm, College of Agriculture, University of Salahaddin, Erbil, during growing season of (2012-2013), the aim of this investigation was to study the effect of $\mathrm{P}$ and Fe fertilizer on some growth characters, yield, yield component and some chemical properties of flax grown in calcareous soil, table (1) shows some chemical and physical properties of the soil(Esmail, 2012). The treatments were arranged in split-plot design with three replicates, the three levels of Triple super phosphate (TSP)were assigned in the main plots $\left(0,50\right.$ and, $100 \mathrm{~kg} \mathrm{TSP} \mathrm{ha}^{-1}$ and the three levels of Cheated iron $(0,4$ and $\left.8 \mathrm{~kg} \mathrm{Fe}-\mathrm{EDDHA} \mathrm{ha}{ }^{-1}\right)$ were assigned in the sub-plot at sowing time.

Seeds were sowing on (1st December, 2012) and seeds were sown in rows $1.5 \mathrm{~m}$ length with $20 \mathrm{~cm}$ apart) and each experimental unit consisted of 5 rows. $100 \mathrm{~kg}$ Nitrogen ha ${ }^{-1}$ was applied in the form of urea $46 \% \mathrm{~N}$ to each plot before seeding. The experiment was done under rain feed condition with annual rainfall of $350 \mathrm{~mm} \mathrm{year}^{-1}$. The seeding rate was $55 \mathrm{~kg} \mathrm{ha}^{-1}$, at full maturity stage, ten plants were taken from each sub- plot (30 plants per treatment) to estimate or recording the following morphological and yield characters :

1-Plant height $(\mathrm{cm})$. 2-Technical stem length $(\mathrm{cm})$. 3- Fruiting zone length $(\mathrm{cm}) .4$-Stem diameter $(\mathrm{mm})$.

5- Number of fruiting branches /plant 6- Number of capsules per plant. 7- Number of seed per capsules.

8- Specific seed weight (seed index) or weight of 1000 seeds (g). 9- Biological yield $\mathrm{kg} \mathrm{ha}^{-1}$.

10 - Seed yield $\mathrm{kg} \mathrm{ha}^{-1}$. 11- Harvesting Index $\%$.

Plants were harvested on 26th of May, 2013; capsules were removed carefully to determine straw yield and seed yield $\left(\mathrm{kg} \mathrm{ha}^{-1}\right)$.Seed oil content was determined by soxhlet extraction apparatus using hexane according to the methods described by (A. O. A. C., 1975). The oil yield was calculated by multiplying seed yield ha-1 by seed oil percentage. Total Nitrogen was determined using Kjeldahl method then protein $\%$ was determined as follow:

Protein $\%=\mathrm{N} \% * 6.25$.

$\mathrm{P}$ and $\mathrm{Fe}$ were determined using spectrophotometer and AAS respectively.

The data were statistically analyzed according to the technique of analysis of variance for Split plot design using SPSS program version 20 the difference among means of treatments were tested using Duncan's multiple range test at level of significant $5 \%$.

Table (1) shows some chemical and physical of the soil of the field experiment.

\begin{tabular}{|c|c|c|c|c|c|c|c|c|}
\hline \multicolumn{3}{|c|}{ PSD $\mathrm{g} \mathrm{kg}^{-1}$} & Textural name & \multicolumn{5}{|c|}{ Water content (Kpa) } \\
\hline Clay & Silt & Sand & \multirow{2}{*}{ Silty clay loam } & \multicolumn{2}{|c|}{ S.P } & \multicolumn{2}{|l|}{ F.C } & W.P \\
\hline 350.7 & 521.3 & 128.0 & & \multicolumn{2}{|c|}{50.52} & \multicolumn{2}{|l|}{26.81} & 14.98 \\
\hline \multicolumn{9}{|c|}{ Soluble ions mmolc. $\mathrm{L}^{-1}$} \\
\hline $\mathrm{Ca}^{2+}$ & $\mathrm{Mg}^{2+}$ & $\mathrm{Na}^{1+}$ & $\mathrm{HCO}_{3}{ }^{1-}$ & $\mathrm{CO}_{3}{ }^{2-}$ & $\mathrm{Cl}^{1-}$ & $\mathrm{SO}_{4}^{2-}$ & $\mathrm{pH}$ & $\mathrm{EC} \mathrm{dS} \mathrm{m}{ }^{-1}$ \\
\hline 2.63 & 0.72 & 0.43 & 2.32 & 0.0 & 0.54 & 1.32 & 7.51 & 0.42 \\
\hline$\underset{\mathrm{kg}^{-1}}{\mathrm{OMg}}$ & $\begin{array}{l}\mathrm{CaCO}_{3} \mathrm{~g} \\
\mathrm{~kg}^{-1}\end{array}$ & \multicolumn{2}{|c|}{ Active $\mathrm{CaCO}_{3} \mathrm{~g} \mathrm{~kg}$} & \multicolumn{5}{|c|}{ Available phosphorus $\left(\mathrm{mg} \mathrm{kg}^{-1}\right.$ soil) } \\
\hline 10.1 & 24.31 & \multicolumn{2}{|c|}{4.52} & \multicolumn{4}{|c|}{2.47} & \\
\hline
\end{tabular}

\section{Results and discussion}

Table (2) shows that the levels of phosphorus affected significantly on Harvesting index, stem diameter, and seed index only, the highest values of them $(0.30,2.11 \mathrm{~mm}$ and $6.53 \mathrm{~g})$ were recorded from( $\mathrm{P}_{1}, \mathrm{P}_{2}$ and $\mathrm{P}_{2}$ treatments respectively) this may be due to the role of applied $\mathrm{P}$ in root growth, nutrient uptake and seed formation (Mengel and Frnest, 2010) . 
Table (2) Effect of levels of phosphorus on yield components.

\begin{tabular}{|c|c|c|c|c|c|c|c|c|c|c|c|}
\hline & 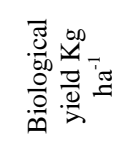 & 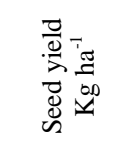 & $\stackrel{\circ}{\stackrel{1}{1}}$ & 离 & 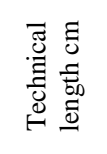 & 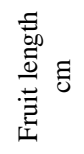 & 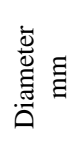 & $\begin{array}{l}\stackrel{0}{z} \\
\overline{0} \\
\vdots \\
\vdots\end{array}$ & $\begin{array}{l}\stackrel{0}{z} \\
0 \\
\bar{z} \\
\tilde{u} \\
\tilde{u}\end{array}$ & 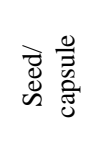 & 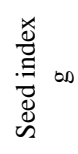 \\
\hline $\mathrm{P}_{0}$ & $5306.93 \mathrm{a}$ & $1274.07 \mathrm{a}$ & $0.24 b$ & $\begin{array}{c}57.74 \\
\text { a }\end{array}$ & $39.80 \mathrm{a}$ & $18.5 \mathrm{a}$ & $\begin{array}{c}1.70 \\
\mathrm{~b}\end{array}$ & $\begin{array}{l}5.4 \\
1 \mathrm{a}\end{array}$ & $\begin{array}{c}20.72 \\
\mathrm{a}\end{array}$ & $8.61 \mathrm{a}$ & $\begin{array}{c}5.65 \\
\mathrm{~b}\end{array}$ \\
\hline $\mathrm{P}_{1}$ & $4310.28 \mathrm{a}$ & $1317.85 \mathrm{a}$ & $0.30 \mathrm{a}$ & $\begin{array}{c}55.12 \\
\mathrm{a}\end{array}$ & $39.49 \mathrm{a}$ & $\begin{array}{c}15.63 \\
\mathrm{a}\end{array}$ & $\begin{array}{c}1.90 \\
\mathrm{ab}\end{array}$ & $\begin{array}{l}5.5 \\
8 \mathrm{a}\end{array}$ & $\begin{array}{c}21.37 \\
\mathrm{a}\end{array}$ & $8.71 \mathrm{a}$ & $\begin{array}{c}5.64 \\
\mathrm{~b}\end{array}$ \\
\hline $\mathrm{P}_{2}$ & $4202.34 \mathrm{a}$ & $1240.52 \mathrm{a}$ & $0.29 \mathrm{a}$ & $\begin{array}{c}60.24 \\
\text { a }\end{array}$ & $41.89 \mathrm{a}$ & $\begin{array}{c}18.24 \\
\mathrm{a}\end{array}$ & $\begin{array}{c}2.11 \\
\mathrm{a}\end{array}$ & $\begin{array}{l}5.8 \\
9 \mathrm{a}\end{array}$ & $\begin{array}{c}23.11 \\
\mathrm{a}\end{array}$ & $8.42 \mathrm{a}$ & $\begin{array}{c}6.53 \\
\mathrm{a}\end{array}$ \\
\hline
\end{tabular}

Table (3) Explains that the levels of applied iron affected significantly on biological yield, Harvest index and seed index, the highest values of them $\left(5994.07 \mathrm{~kg} \mathrm{ha}^{-1}, 0.30\right.$ and $6.39 \mathrm{~g}$ ) were recorded from treatments $\left(\mathrm{Fe}_{1}, \mathrm{Fe}_{0}\right.$ and $\left.\mathrm{Fe}_{2}\right)$ respectively this may be due to the role of iron in chlorophyll formation then increase in biological yield and seed index (Mengel and Frnest, 2010).

Table (3) Effect of levels of Iron on yield components on flax.

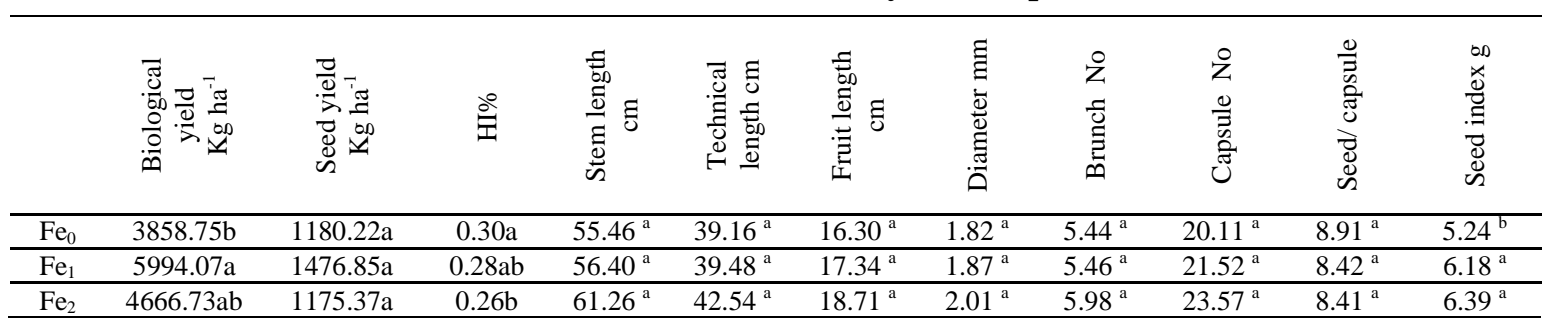

The statistical analysis indicated that the interaction treatments influenced significantly at level of significant 0.05 on biological yield ,harvest index and seed index only (table 4), the highest values (7031.07 kg.ha $\left.{ }^{-1}, 0.31 \% 7.09 \mathrm{~g}\right)$ were recorded from treatment combinations $\left(\mathrm{P}_{0} \mathrm{Fe}_{2}, \mathrm{P}_{2} \mathrm{Fe}_{0}\right.$ and $\left.\mathrm{P}_{2} \mathrm{Fe}_{1}\right)$ respectively, while the lowest values $2986.20 \mathrm{~kg} \cdot \mathrm{ha}^{-1}, 0.21$ and $4.58 \mathrm{~g}$ were obtained from $\left(\mathrm{P}_{0} \mathrm{Fe}_{0}, \mathrm{P}_{0} \mathrm{Fe}_{1}\right.$ and $\left.\mathrm{P}_{1} \mathrm{Fe}_{0}\right)$ this may be due to the single role of phosphorus as mentioned before or this may be due to the single effect of the studied factors or the interaction between $\mathrm{P}_{2}$ and $\mathrm{Fe}_{1}$ may created the best condition for plant growth.( Hocking and Jand, 1993 and Mengel and Frnest, 2010).

Table (4): Interaction effect of $P$ and Fe on yield components and growth characters of flax.

\begin{tabular}{|c|c|c|c|c|c|c|c|c|c|c|c|}
\hline & 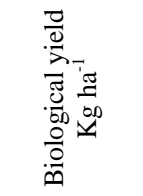 & 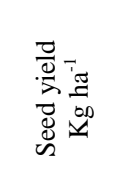 & $\begin{array}{l}0^{\circ} \\
\text { 国 }\end{array}$ & 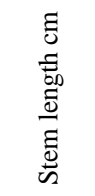 & 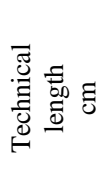 & 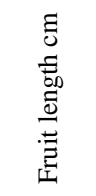 & 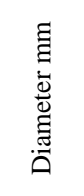 & 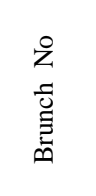 & 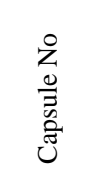 & 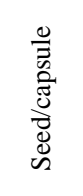 & 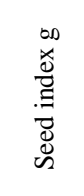 \\
\hline $\mathrm{P}_{0} \mathrm{Fe}_{0}$ & $2986.20^{\mathrm{d}}$ & $905.33^{\mathrm{a}}$ & $0.30^{\mathrm{ab}}$ & $55.73^{\mathrm{a}}$ & $38.90^{\mathrm{a}}$ & $16.83^{\mathrm{a}}$ & $1.58^{\mathrm{a}}$ & $4.77^{\mathrm{a}}$ & $15.63^{a}$ & $8.57^{\mathrm{a}}$ & 5.13 \\
\hline $\mathrm{P}_{0} \mathrm{Fe}_{1}$ & $5903.51^{\mathrm{ab}}$ & $1271.11^{\mathrm{a}}$ & $0.21^{\mathrm{c}}$ & $56.07^{\mathrm{a}}$ & $37.93^{a}$ & $19.80^{\mathrm{a}}$ & $1.75^{\mathrm{a}}$ & $5.60^{\mathrm{a}}$ & $21.53^{a}$ & $6.97^{\mathrm{a}}$ & $5.89^{\mathrm{ab}}$ \\
\hline $\mathrm{P}_{0} \mathrm{Fe}_{2}$ & $7031.07^{\mathrm{a}}$ & $1645.78^{\mathrm{a}}$ & $0.23^{\mathrm{bc}}$ & $61.43^{\mathrm{a}}$ & $42.57^{\mathrm{a}}$ & $18.87^{\mathrm{a}}$ & $1.83^{\mathrm{a}}$ & $5.57^{\mathrm{a}}$ & $25.00^{\mathrm{a}}$ & $6.71^{\mathrm{a}}$ & $5.91^{\mathrm{ab}}$ \\
\hline $\mathrm{P}_{1} \mathrm{Fe}_{0}$ & $5138.73^{\text {abcd }}$ & $1549.55^{\mathrm{a}}$ & $0.29^{\mathrm{ab}}$ & $52.93^{\mathrm{a}}$ & $37.13^{\mathrm{a}}$ & $15.80^{\mathrm{a}}$ & $1.8^{\mathrm{a}}$ & $5.37^{\mathrm{a}}$ & $20.13^{a}$ & $7.61^{\mathrm{a}}$ & $4.58^{\mathrm{c}}$ \\
\hline $\mathrm{P}_{1} \mathrm{Fe}_{1}$ & $4563.31^{\mathrm{bcd}}$ & $1535.67^{\mathrm{a}}$ & $0.34^{\mathrm{a}}$ & $59.47^{\mathrm{a}}$ & $42.23^{\mathrm{a}}$ & $17.23^{\mathrm{a}}$ & $2.14^{\mathrm{a}}$ & $6.00^{\mathrm{a}}$ & $23.57^{\mathrm{a}}$ & $7.31^{\mathrm{a}}$ & $6.17^{\mathrm{ab}}$ \\
\hline $\mathrm{P}_{1} \mathrm{Fe}_{2}$ & $3228.80^{\mathrm{cd}}$ & $868.33^{\mathrm{a}}$ & $0.26^{\mathrm{ab}} \mathrm{c}$ & $57.70^{\mathrm{a}}$ & $41.43^{\mathrm{a}}$ & $16.27^{\mathrm{a}}$ & $2.14^{\mathrm{a}}$ & $6.20^{\mathrm{a}}$ & $24.57^{\mathrm{a}}$ & $6.97^{\mathrm{a}}$ & $6.00^{\mathrm{ab}}$ \\
\hline $\mathrm{P}_{2} \mathrm{Fe}_{0}$ & $3451.31^{\mathrm{cd}}$ & $1085.77^{\mathrm{a}}$ & $0.31^{\mathrm{a}}$ & $60.17^{\mathrm{a}}$ & $41.40^{\mathrm{a}}$ & $18.43^{\mathrm{a}}$ & $2.11^{\mathrm{a}}$ & $5.40^{\mathrm{a}}$ & $22.63^{\mathrm{a}}$ & $7.07^{\mathrm{a}}$ & $6.50^{\mathrm{a}}$ \\
\hline $\mathrm{P}_{2} \mathrm{Fe}_{1}$ & $5415.38 \mathrm{a}^{\mathrm{bc}}$ & $1623.78^{\mathrm{a}}$ & $0.29^{\mathrm{ab}}$ & $62.87^{\mathrm{a}}$ & $42.83^{\mathrm{a}}$ & $20.03^{\mathrm{a}}$ & $2.07^{\mathrm{a}}$ & $6.07^{\mathrm{a}}$ & $22.13^{\mathrm{a}}$ & $7.64^{\mathrm{a}}$ & $7.09^{\mathrm{a}}$ \\
\hline $\mathrm{P}_{2} \mathrm{Fe}_{2}$ & $3740.33^{\mathrm{bcd}}$ & $1012.00^{\mathrm{a}}$ & $0.28^{\mathrm{abc}}$ & $52.97^{\mathrm{a}}$ & $39.10^{\mathrm{a}}$ & $13.87^{\mathrm{a}}$ & $1.76^{\mathrm{a}}$ & $5.37^{\mathrm{a}}$ & $20.40^{\mathrm{a}}$ & $7.64^{\mathrm{a}}$ & $6.16^{\mathrm{ab}}$ \\
\hline
\end{tabular}

Table (5) refers to significant effect of phosphorus on oil content $(\%)$, oil yield ( $\mathrm{kg}^{-h^{-1}}$ ), phosphorus $\%$, protein $\%$ Fe concentration ( $\mathrm{ppm}$ ) of flax , the highest value of them $\left(21.92 \%, 288.87 \mathrm{~kg} . \mathrm{ha}^{-1}, 6.00 \%\right.$ and $24.31 \%$ and141.89 ppm) were recorded from $\mathrm{P}_{1}$ treatment except the highest value of $\mathrm{P} \%$ in flax $(6.0 \%)$ and 
Fe concentration (141.89 ppm) were recorded from $\mathrm{P}_{2}$ treatment respectively, this explain that the application of phosphorus fertilizer to a certain level $\left(\mathrm{P}_{1}\right)$ caused a significant increase in most of the studied character , this may be due to obtaining the best nutrient balance in plant in case of treatment $\left(\mathrm{P}_{1}\right)$ but at the highest level of $\mathrm{P}$ (treatment $\mathrm{P}_{2}$ ) the concentration of $(\mathrm{P})$ increased in plant then caused decrease in protein $\%$ of plant (table 5).

Table (5) Effect of levels of phosphorus on chemical characters of flax.

\begin{tabular}{cccccc}
\hline & Oil\% & Oil yield & $\mathrm{P} \%$ & protein & Fe ppm \\
\hline $\mathrm{P}_{0}$ & $20.47^{\mathrm{b}}$ & $260.80 \mathrm{a}$ & $4.07^{\mathrm{c}}$ & $21.51^{\mathrm{b}}$ & $112.60^{\mathrm{b}}$ \\
\hline $\mathrm{P}_{1}$ & $21.92^{\mathrm{a}}$ & $288.87^{\mathrm{a}}$ & $4.73^{\mathrm{b}}$ & $24.31^{\mathrm{a}}$ & $123.11^{\mathrm{b}}$ \\
\hline $\mathrm{P}_{2}$ & $18.40^{\mathrm{c}}$ & $228.26^{\mathrm{b}}$ & $6.00^{\mathrm{a}}$ & $23.70^{\mathrm{a}}$ & $141.89^{\mathrm{a}}$ \\
\hline
\end{tabular}

Table(6) indicated to significant effect of iron on oil\%,phosphorus content, protein\% and $\mathrm{Fe}$ concentration (ppm) of flax , the highest values of them $(21.40 \%, 5.35 \%, 24.53 \%$ and 158.80$)$ were recorded from treatments $\left(\mathrm{Fe}_{0}, \mathrm{Fe}_{2}, \mathrm{Fe}_{0}\right.$ and $\left.\mathrm{Fe}_{2}\right)$ respectively .

Table (6) Effect of levels of Iron on some chemical properties of flax.

\begin{tabular}{cccccc}
\hline & Oil\% & Oil yield & P\% & protein\% & Fe ppm \\
\hline $\mathrm{Fe}_{0}$ & $21.40^{\mathrm{a}}$ & $252.57 \mathrm{a}$ & $4.90^{\mathrm{b}}$ & $24.53^{\mathrm{a}}$ & $112.60^{\mathrm{b}}$ \\
\hline $\mathrm{Fe}_{1}$ & $20.15^{\mathrm{b}}$ & $297.58 \mathrm{a}$ & $4.55^{\mathrm{c}}$ & $22.93^{\mathrm{ab}}$ & $146.89^{\mathrm{a}}$ \\
\hline $\mathrm{Fe}_{2}$ & $19.23^{\mathrm{c}}$ & $226.02 \mathrm{a}$ & $5.35^{\mathrm{a}}$ & $22.06^{\mathrm{c}}$ & $158.80^{\mathrm{a}}$ \\
\hline
\end{tabular}

The highest oil and protein percentage may be due to the dilution effect since oil yield, seed yield \& nitrogen content of seed with decrease in seed yield in $\mathrm{Fe}_{2}$ then the highest protein contented was recorded from control treatments. The soil or foliar application of $\mathrm{Fe}, \mathrm{Cu}$ and $\mathrm{B}$ significantly increased $\mathrm{N}$ and $\mathrm{P}$ uptake from soil and increased their content in flax plants (El-Nagdy et al., 2010 and You et al., 2007).

Table (7) shows the significant effect of interaction treatments at level of significant $5 \%$ on studied chemical properties ,the highest value of oil\%, oil yield, $\mathrm{P} \%$, protein $\%$ and $\mathrm{Fe}$ concentration were recorded $(23 \%, 346.47,6.65,27.47$ and 151.90$)$ from $\left(\mathrm{P}_{0} \mathrm{Fe}_{1}, \mathrm{P}_{1} \mathrm{Fe}_{0}, \mathrm{P}_{2} \mathrm{Fe}_{1}, \mathrm{P}_{1} \mathrm{Fe}_{0}\right.$ and $\left.\mathrm{P}_{2} \mathrm{Fe}_{2}\right)$ respectively. This may be due to the single effect of the studied factors. Or the interaction between levels of phosphorus and iron created different growth conditions for plant growth which caused above results (A. O. A. C., 1975).

Table (7) Interaction effect of $P$ and Fe on some chemical properties of flax.

\begin{tabular}{cccccc}
\hline & Oil\% & Oil yield & P\% & Protein\% & Fe ppm \\
\hline $\mathrm{P}_{0} \mathrm{Fe}_{0}$ & $21.15^{\mathrm{bc}}$ & $190.68 \mathrm{ab}$ & $4.15^{\mathrm{cd}}$ & $20.94^{\mathrm{c}}$ & $109.70^{\mathrm{a}}$ \\
\hline $\mathrm{P}_{0} \mathrm{Fe}_{1}$ & $23.55^{\mathrm{a}}$ & $299.66 \mathrm{ab}$ & $3.55^{\mathrm{d}}$ & $26.50^{\mathrm{ab}}$ & $111.50^{\mathrm{a}}$ \\
\hline $\mathrm{P}_{0} \mathrm{Fe}_{2}$ & $16.70^{\mathrm{d}}$ & $278.23 \mathrm{ab}$ & $4.50^{\mathrm{cd}}$ & $17.09^{\mathrm{d}}$ & $116.60^{\mathrm{a}}$ \\
\hline $\mathrm{P}_{1} \mathrm{Fe}_{0}$ & $22.35^{\mathrm{ab}}$ & $346.47 \mathrm{a}$ & $4.90^{\mathrm{bc}}$ & $27.47^{\mathrm{a}}$ & $113.11^{\mathrm{a}}$ \\
\hline $\mathrm{P}_{1} \mathrm{Fe}_{1}$ & $23.45^{\mathrm{a}}$ & $308.55 \mathrm{ab}$ & $4.90^{\mathrm{bc}}$ & $22.56^{\mathrm{bc}}$ & $119.00^{\mathrm{a}}$ \\
\hline $\mathrm{P}_{1} \mathrm{Fe}_{2}$ & $20.70^{\mathrm{c}}$ & $303.65 \mathrm{ab}$ & $5.65^{\mathrm{b}}$ & $25.19^{\mathrm{ab}}$ & $137.22^{\mathrm{b}}$ \\
\hline $\mathrm{P}_{2} \mathrm{Fe}_{0}$ & $16.95^{\mathrm{d}}$ & $224.60 \mathrm{ab}$ & $5.70^{\mathrm{b}}$ & $19.38^{\mathrm{cd}}$ & $132.89^{\mathrm{b}}$ \\
\hline $\mathrm{P}_{2} \mathrm{Fe}_{1}$ & $17.55^{\mathrm{d}}$ & $275.29 \mathrm{ab}$ & $6.65^{\mathrm{a}}$ & $26.53^{\mathrm{ab}}$ & $140.88^{\mathrm{bc}}$ \\
\hline $\mathrm{P}_{2} \mathrm{Fe}_{2}$ & $19.95^{\mathrm{c}}$ & $177.53 \mathrm{~b}$ & $4.40^{\mathrm{cd}}$ & $22.91^{\mathrm{bc}}$ & $151.90^{\mathrm{c}}$ \\
\hline
\end{tabular}

\section{Journal Papers:}

\section{References}

[1] Bakry, A.B:Elewa.T.A and Ali, A .M (2012).Effect of Fe foliar application on yield and quality traits of some flax varieties grown under newly reclaimed sandy soil. Australian J. of Basic and Applied Science. 6(7)532-536. ISSN1991-8178.

[2] Esmail, A.O.(2012) Effect of soil phosphorus equilibrium on P-availability for wheat using solubility diagram and DRIS-chart methods. Journal of University of Kirkuk for Agriculture Sciences Vol. (3), No.2.

[3] Berti, M.; Susana, F.; Rosemarie, W and Felicitas, H. (2009) .Flaxseed response to N, P, K fertilization in South Central Chile. Chilean Journal of Agricultural research 69(2):145-153.

[4] Cynthia,G.;M. Monreal: B. Irvine: D. McLaren and R. Mohr (2004). The role of phosphorus fertility and mycorrhyza in flax production. Agriculture and Agri-Food Canada, Brandon Research Center, Brandon, MB .cgrant@em.agr.ca (204) 726-7650.

[5] El-Nagdy, G. A.; Dalia,M.A.N.;Eman, A. E. and Gelan, S. A. EL (2010).Response of flax plant (Linum usitatissumum L) to treatments with mineral and Bio-fertilizers from Nitrogen and Phosphorus .Journal of American science :6(10).

[6] Esmail, A.O. (2012) Effect of soil phosphorus equilibrium on P-availability for wheat using solubility diagram and DRIS-chart methods. Journal of University of Kirkuk for Agriculture Sciences. Vol. (3), No.2. 
[7] Grant .C.A, D.N. Flaten, D. J. Tomasiewicz,S.C.Sheppard and A.M.Johnston (2012) The importance of early season phosphorus nutrition. (cgrant@em.agr.ca).

[8] Hocking ,P. and Jand A. P.(1993). Phosphorus nutrition of linseed (Linum usitatissimum L.) as affected by nitrogen supply: effects on vegetative development and yield components. Field Crop Research, Vol. 32, Issues 1-2. (101-114).

[9] Hussein, M .M.M. (2007).Response of some flax genotypes to bio and nitrogen fertilization. Zagazig J. Agric. Res. 34 (5):815-844.

[10] Ibrahim, H.M (2009).Effect of sowing date and N- fertilizer levels on seed yield, some yield components and oil content in flax J.Agri.Res. 54(1):19-28.

[11] Khalifa,R,Kh,M.;Manal,F.M.;Bakry,A.B. and Zeidan,M.S.(2011) Response of some flax varieties to micronutrients foliar application under newly reclaimed sandy soil. Australian Journal of Basic and Applied Science. 5(8):1328-1334.

[12] Mousa, M.A.; E.A.E. and Zedan, Z.S. (2010). Effect of nitrogen fertilizers and some micro nutrient on flax yield and chemical composition characters. Journal of Plant Production, Mansura University. 2090-3677.

[13] Mousavi, S.R. (2011).Zinc in crop production with phosphorus. Australian .J. of Basic and Applied Sciences: 5(9):1503-1509.

[14] Nofal, O.A:M.S. Zedian and B.A. Bakry (2011).Flax yield and quality traits as affected by Zn foliar application under newly reclaimed sandy soil .Journal of Applied Science Research, 7(9):1361-1367.

[15] You J. Cynthia, A, G. and Loraine, D, B (2007). Growth and nutrient response of flax and durum wheat to phosphorus and zinc fertilizers. Canadian Journal of Plant Science, 87(3): 461-470.

\section{Books:}

[16] A.O.A.C (1975) .Association of Official Analytical Chemists .Official methods of Analysis $12^{\text {th }}$ Ed.Washington .D.C. USA.

[17] El-Hariri,D.M.; M.S.Hassanein and M.A.Ahmed (1998) .Proceedings of the Hemp flax and other best fibrous plants ,production ,technology \& ecology -symposium institute of natural fibers ,Poznan, Poland ,pp:20-26.

[18] Lafoand, G.P: C.A.Grant:A.M. Johnton: D.W.Mcandrew and W. E. May (2003). Nitrogen and phosphorus fertilizer management of No-till flax.

[19] McKenzie, R H and Allan, A. (2013). Phosphorus Fertilizer Application in Crop Production. Toll-free in Alberta at $310-$ farm 3276 for agriculture information.

[20] Mengel, K and Frnest, A.K (2010). Principles of Plant Nutrition. International Potash Institute. P.O. Box, CH-3048 WorblanfenBern/ Switzerland.

[21] Roy,R.N, A. Finck, G.J. Blair and H. L. S. Tandon (2007).Plant nutrition for food secretary . Discovery publishing house. New Delhi-110002.India. 